Vol. 2, No. 2, Juli 2018, 118-128

Available Online at https://ejournal.warmadewa.ac.id/index.php/kulturistik DOI: dx.doi.org/10.22225/kulturistik.2.2.718

\title{
PENGUASAAN VERBA BENTUK-TE UNTUK MENYATAKAN KEGIATAN SEDANG BERLANGSUNG DAN KEGIATAN BERURUTAN PADA PESERTA DIDIK KELAS XI IPA SMA PGRI 6 DENPASAR TAHUN AJARAN 2016/2017
}

\author{
Dewa Gede Agung Aditya K \\ Universitas Udayana \\ dewadegungagung@gmail.com \\ I Nyoman Suparwa \\ Universitas Udayana \\ suparwa_nym@yahoo.co.id \\ Made Sri Satyawati \\ Universitas Udayana \\ srisatyawati@gmail.com
}

\begin{abstract}
ABSTRAK
Penelitian ini bertujuan untuk mengetahui (1) kemampuan penguasaan verba bentuk-te pada peserta didik kelas XI IPA SMA PGRI 6 Denpasar; (2) kesulitan yang dihadapi oleh peserta didik kelas XI IPA SMA PGRI 6 Denpasar dalam penggunaan verba bentuk-te. Penelitian dengan rancangan deskriptif kualitatif ini memiliki subjek penelitian, yaitu siswa kelas XI IPA SMA PGRI 6 Denpasar dan objek penelitian, yaitu verba bentuk-te. Data dikumpulkan melalui metode tes. Data dianalisis dengan deskriptif kualitatif dan kuantitatif. Hasil penelitian menunjukkan bahwa (1) kemampuan penguasaan verba bentuk-te pada peserta didik kelas XI IPA SMA PGRI 6 Denpasar termasuk dalam kategori kurang, dengan nilai rata-rata yaitu 50 . Terdapat enam orang siswa $24 \%$ yang memperoleh nilai cukup dan sembilan belas orang siswa 76\% siswa yang memperoleh nilai kurang; (2) kesulitan dihadapi peserta didik kelas XI IPA SMA PGRI 6 Denpasar dalam penggunaan verba bentuk-te yang menyatakan kegiatan sedang berlangsung dan kegiatan yang berurutan berdasarkan hasil tes bahwa siswa masih bingung dengan penggunaan verba bentuk -te antara konsonan rangkap /t/ dan / $/$ / yang tidak rangkap, misalnya verba $m i-r u$ dalam bentuk -te menjadi mi-te bukan mi-tte karena verba mi-ru termasuk golongan ichidandoushi hanya menggantikan gobi(ru) menjadi /te/ dan ditempelkan dengan morfem dasar verba $(m i)$ sehingga menjadi mi-te.
\end{abstract}

Kata kunci: verba bentuk-te, kegiatan sedang berlangsung dan berurutan, SMA PGRI 6 Denpasar

\begin{abstract}
[Title: Mastering verb form of -te for declaring ongoing and sequential activity on the students of grade XI IPA SMA PGRI 6 Denpasar Academic Year 2016/2017] This research is aimed to know (1) the ability in mastering verb form of -te on the students of grade XI IPA SMA PGRI 6 Denpasar. (2) The difficulty is faced by the students of grade XI IPA SMA PGRI 6 Denpasar in the use of verb form of -te. The research with this qualitative descriptive design has research subject, that is the students of grade XI IPA SMA PGRI 6 Denpasar and research object, that is verb form of -te. The data is collected through test method. The data is analysed with qualitative and quantitative. The result of
\end{abstract}


Vol. 2, No. 2, Juli 2018, 119

Available Online at https://ejournal.warmadewa.ac.id/index.php/kulturistik

DOI: dx.doi.org/10.22225/kulturistik.2.2.718

the research shows that (1) the ability in mastering the verb form of -te on the students of grade XI IPA SMA PGRI 6 Denpasar belong to lack category, average mark achieved is 50. There are six students $24 \%$ students get enough mark and 19 students $76 \%$ students achieved mark lack;(2) the dificulty is faced by the sudents of grade XI IPA SMA PGRI 6 Denpasar in the use of verb form of -te stated the running activity and ordering activity based on the test result that is the students still confused with the use of verb form of -te between doublé consonant /t/ and /t/ which is not doublé such as mi-ru verb in the verb form of -te become mi-te not mi-tte because mi-ru verb belong to ichidandoushi which is replace gobi(ru) become /te/ and attach with basic morferm verb (mi) so become mi-te.

Keywords: verb form of -te, ongoing and sequential activity, SMA PGRI 6 Denpasar.

\section{PENDAHULUAN}

Verba digunakan untuk menyatakan suatu tindakan, keberadaan, pengalaman, atau pengertian dinamis lainnya. Peran verba pada umumnya berperan sebagai predikat dalam suatu klausa atau kalimat. Verba adalah kata yang menggambarkan proses, perbuatan,atau keadaan (Depdiknas, 2008: 929).

Verba dalam bahasa Indonesia mau pun bahasa lainnya di dunia memiliki peran penting dalam menentukan makna kalimat. verbalah yang menentukan inti atau isi dalam kalimat. Menurut Darlina "The predicate, which is in the form of verb, has the ability to bind arguments to create a clausal structure. Therefore, it is possible that one verb binds one argument, two arguments and three arguments, highly depending on the type of the verb" (Darlina \& Al, 2018).

Verba dalam bahasa Indonesia selalu diletakkan di tengah kalimat sebelum objek dari kalimat tersebut. Untuk menyatakan aktivitas yang sedang berlangsung dalam bahasa Indonesia menggunakan partikel "sedang" diletakkan sebelum verba, contohnya "sedang makan", "sedang belajar", dll. Hal itu tidak mengalami proses afiksasi.

Berbeda dengan bahasa Indonesia, bahasa Jepang memiliki keunikan tersendiri terutama dalam hal gramatikal. Kelas kata verba dalam bahasa Jepang sebagian besar dapat diidentifikasi dengan berbagai akhiran konjugasional yang dapat dilekatkan kepada aspek kala (Kartika, 2006: 120). Misalnya, bentuk kala bukan lampau berakhiran (-ru) dilekatkan secara eksklusif pada akar verba. Akar pada tulisan ini mengacu pada unit bermakna yang tidak dapat diberikan analisis morfologis lebih lanjut. Contoh tabe-ru 'makan' dan yom-u 'membaca'. Jika akhiran(-ru) ditambahkan pada akar verba, hasilnya ialah bentuk verba kala bukan lampau.

Sedangkan dalam bahasa indonesia jika merujuk pada kasus gramatikal yang serupa tidak mengalami proses konjugasi pada verba. Kala dalam bahasa indonesia dapat diungkapkan secara leksikal melalui pewatas verba atau dalam bentuk kata keterangan waktu. contohnya untuk mengungkapkan kala yang menyatakan keakanan (future) dapat digunakan pewatas verba akan; untuk menyatakan kala lampau dapat digunakan kata keterangan waktu kemarin; dan untuk menyatakan kala mendatang dapat digunakan kata keterangan waktu besok. Pengungkapan kala secara leksikal ini tidak mengubah atau memengaruhi bentuk morfologis pada fungsi predikat bahasa indonesia.

Verba atau doushi yang berfungsi menjadi predikat dalam suatu kalimat akan mengalami perubahan bentuk (katsuyou) sesuai dengan fungsi gramatikal, semantik dan berpotensi menjadi sebuah kalimat. Perubahan bentuk 
Vol. 2, No. 2, Juli 2018, 120

Available Online at https://ejournal.warmadewa.ac.id/index.php/kulturistik DOI: dx.doi.org/10.22225/kulturistik.2.2.718

(Katsuyookei) terdapat enam macam bentuk konjugasi, salah satunya yaitu verba bentuk -te (Sutedi, 2003: 42).

Verba bentuk -te adalah kata kerja yang digunakan untuk menyatakan atau menggabungkan beberapa kegiatan atau kejadian yang berurutan. Selain itu, verba bentuk -te digunakan juga untuk menyatakan kegiatan yang sedang berlangsung, menyatakan suatu keadaan,dan menyatakan bentuk perintah.

Dalam proses pembentukan verba ke bentuk-te terdapat pattern atau aturan-aturan khusus yang harus diperhatikan, namun aturan-atauran tersebut tidak sepenuhnya bisa diaplikasikan dalam proses konjugasi verba bentuk-te. Ada beberapa pengecualian khusus yang wajib diperhatikan dan berbeda dengan pattern verba umumnya. Proses morfologis atau konjugasi yang tidak wajar dan tidak lazim dianggap sebagai perkecualian yang tidak memerlukan penjelasan lebih lanjut. Oleh karena itu, verba yang termasuk dalam perkecualian konjugasi bentuk-te wajib dijelaskan secara khusus untuk menghindari kesalahan berulang pada peserta didik (Simpen, 2008).

Dalam pelajaran bahasa asing, sesuai dengan kurikulum yang berlaku, khususnya pelajaran bahasa Jepang, peserta didik dituntut untuk menghafalkan golongan kata kerja dan perubahan verba dari setiap golongan kata kerja agar pembelajaran tersebut bisa berjalan lancar. Hal ini dialami oleh peserta didik kelas XI SMA PGRI 6 Denpasar. Berdasarkan hasil ulangan harian mengenai perubahan bentuk verba-te sebagian besar peserta didik mengalami kendala pada kata kerja bentuk-te. Dari 25 siswa, sebanyak 16 siswa yang belum paham perubahan verba bentuk-te dan hanya 9 siswa yang sudah memahami dan bisa menggunakan verba bentuk-te. Hasil tersebut menggambarkan bahwa sebagian besar peserta didik tidak menguasai perubahan verba bentuk-te dengan baik dan benar.

Penelitian mengenai penguasaan aspek verba te-imasu sudah pernah dilakukan oleh Pande Wayan Mahardi Nugraha. Pada penelitian tersebut dinyatakan bahwa tujuan penelitian ialah untuk (a) mengetahui kemampuan peserta didik dalam penguasaan aspek verba te-imasu, (b) mengetahui kendala yang dihadapi peserta didik dalam penguasaan aspek verba te-imasu. Kemampuan peserta didik dalam penguasaan verba te-imasu tergolong cukup baik, dilihat dari rata-rata yang diperoleh yaitu 67,94. Berdasarkan hasil tes, 4 peserta didik tergolong dalam kategori sangat baik, 22 peserta didik tergolong dalam kategori baik, 16 peserta didik tergolong dalam kategori cukup, 6 peserta didik tergolong dalam kategori kurang, dan 2 peserta didik tergolong sangat kurang. Penelitian ini memiliki relevansi dengan penelitian terdahulu, dengan subjek yang berbeda terhadap penelitian pertama, penelitian ini memiliki relevansi dengan penelitian yang dilaksanakan peneliti sebelumnya (Nugraha, 2011).

Verba bentuk sambung (te-kei) merupakan verba yang digunakan untuk menyatakan kegiatan yang menandakan aspek progresif, hasil suatu perbuatan, dan kontinuatif. Perubahan verba ke dalam bentuk-te ada dua cara, yakni bermula dari verba bentuk masu dan dari verba bentuk leksem. Cara yang pertama sering diaplikasikan dalam pendidikan bahasa Jepang tingkat dasar, seperti buku Sakura 1 sampai buku Minna no Nihongo menggunakan bentuk masu untuk mengubah verba bentuk-te dan bentuk kamus ke bentuk-te. Jika pembelajar sudah diberikan pengetahuan tentang pembagian jenis verba dengan menggunakan huruf Jepang, akan lebih mudah untuk mengetahui perubahan bentuk verba (Sutedi, 2003: 54). 
Vol. 2, No. 2, Juli 2018, 121

Available Online at https://ejournal.warmadewa.ac.id/index.php/kulturistik

DOI: dx.doi.org/10.22225/kulturistik.2.2.718

\section{METODE}

Pada penelitian ini kualitatif digunakan untuk menjabarkan data-data yang bersifat deskriptif tentang kesulitan yang dihadapi peserta didik kelas XI IPA SMA PGRI 6 Denpasar dalam penguasaan verba bentuk-te. Pendekatan kuantitatif memberikan makna dalam hubungannya dengan penghitungan angka statistik bukan makna secara kebahasaan (Sarwono, 2006: 258). Pada penelitian ini pendekatan kuantitatif digunakan untuk memaparkan data yang bersifat kuantitatif atau angka-angka statistik, pada hasil tes.

Lokasi penelitian dilaksanakan di Sekolah Menengah Atas (SMA) PGRI 6 Denpasar yang bertempat di Jalan Merdeka X, Denpasar Timur, Provinsi Bali. SMA PGRI 6 merupakan sekolah swasta yang ada di Kota Denpasar yang bernaung di bawah Perkumpulan Pembina Lembaga Pendidikan Dasar dan Menengah PGRI Kota Denpasar yang berlokasi di Desa Sumerta Kelod, Kecamatan Denpasar Timur, Kota Denpasar.

Penelitian ini merupakan penelitian deskriptif untuk menggambarkan data yang melekat pada subjek secara apa adanya. Data dianalisis dengan kuantitatif dan kualitatif. Deskriptif kualitatif digunakan untuk memperoleh gambaran yang jelas, objektif, sistematis dan cermat mengenai fakta-fakta yang didapat dari sifat populasi tertentu, sehingga memerlukan ketajaman análisis, objektivitas, dan sistematis dalam interpretasi data terkait fenomana yang melekat pada sampel.

Instrumen dalam penelitian ini adalah tes. Tes digunakan untuk memperoleh data mengenai penguasaan verba bentuk-te dan kesulitan peserta didik dalam penguasaan verba bentuk-te. Evaluasi yang dilakukan adalah menilai tes yang dikerjakan oleh peserta didik berdasarkan kriteria penilaian yang telah ditentukan. Nilai-nilai yang diperoleh peserta didik menjadi cerminan kemampuan peserta didik dalam penguasaan verba bentuk-te.

Jenis data berupa data kualitatif dan data kuantitatif. Data kualitatif berasal dari tes yang dilakukan untuk mengetahui kesulitan yang dialami peserta didik dalam penguasaan verba bentuk-te yang menyatakan kegiatan yang sedang berlangsung dan kegiatan berurutan. Sebaliknya, data kuantitatif berupa hasil tes dijelaskan dengan perhitungan statistik atau angka untuk mengetahui kemampuan penguasaan verba bentuk-te pada peserta didik kelas XI SMA PGRI 6 Denpasar.

Sumber data dalam penelitian ini adalah peserta didik kelas XI IPA semester 2 SMA PGRI 6 Denpasar tahun ajaran 2016/2017 yang berjumlah 25 orang.

Tes diberikan dalam bentuk tertulis berupa kata kerja rumpang dalam karangan atau kalimat yang dilengkapi oleh peserta didik. Soal yang diberikan berjumlah sepuluh butir. Tujuan tes ini digunakan untuk mengetahui penguasaan verba bentuk-te yang menyatakan bentuk sedang dan berurutan pada peserta didik kelas XI IPA SMA PGRI 6 Denpasar.

Metode yang digunakan untuk mengumpulkan data dalam penelitian adalah pemberian tes. Data dikumpulkan berdasarkan hasil tes peserta didik dalam penguasaan verba bentuk-te untuk mengetahui kemampuan peserta didik dalam penguasaan verba bentuk-te dan kesulitan yang dihadapi peserta didik.

Adapun data yang dikumpulkan dan instrumen yang digunakan secara keseluruhan dapat disajikan sebagai berikut. 
Vol. 2, No. 2, Juli 2018, 122

Available Online at https://ejournal.warmadewa.ac.id/index.php/kulturistik DOI: dx.doi.org/10.22225/kulturistik.2.2.718

Tabel 1 Jenis data, Pengumpulan data, dan Instrumen

\begin{tabular}{llll}
\hline No & Jenis data & $\begin{array}{l}\text { Metode pengumpulan } \\
\text { data }\end{array}$ & Instrumen \\
\hline 1 & $\begin{array}{l}\text { Kemampuan penguasaan verba bentuk } \\
\text {-te. }\end{array}$ & Metode tes & lembar tes \\
2 & $\begin{array}{l}\text { kesulitan yang dihadapi peserta didik } \\
\text { dalam penguasaan verba bentuk-te }\end{array}$ & Metode tes & lembar tes \\
\hline
\end{tabular}

Dari tabel di atas diketahui bahwa data yang diperoleh dari instrumen yang berupa lembar tes disajikan dalam jenis data kemampuan penguasaan verba bentuk-te dan kesulitan dalam penguasaan verba bentuk-te. Selanjutnya, dianalisis untuk mengetahui kemampuan penguasaan verba bentuk-te dalam bahasa Jepang.

Dalam penelitian ini data yang diperoleh dianalisis secara kuantitatif dan ada pula yang dianalisis berupa kata yang sering disebut dengan data deskriptif kualitatif atau penggambaran atas data yang sebenarnya. Rancangan ini dipakai sebagai prosedur dalam mengidentifikasi atau menggambarkan fenomena yang terjadi secara apa adanya. Dari tes dianalisis menggunakan teknik deskriptifkualitatif. Hasil analisis data tersebut dipaparkan secara apa adanya dengan menggunakan kata-kata sehingga diperoleh suatu simpulan.

\section{PEMBAHASAN}

Hasil penelitian berfokus pada analisis kemampuan verba bentuk-te pada peserta didik kelas XI IPA SMA PGRI 6 Denpasar yang mencakup data kuantitatif dan kualitatif. Data kuantitatif diperoleh dari hasil tes pembelajaran verba bentuk-te yang berupa nilai atau angka.

Hasil tes tersebut dideskripsikan dengan apa adanya untuk mengetahui kemampuan verba bentuk-te dalam proses pembelajaran.

Pada saat pembelajaran bahasa Jepang, peneliti memberikan tes untuk mendapatkan data mengenai kemampuan peserta didik dalam menguasai verba bentuk-te.

Sesuai dengan rencana yang ditetapkan sebelumnya bahwa tes terdiri atas sepuluh butir soal berbentuk kata kerja rumpang. Hasil yang didapat melalui tes menunjukkan ternyata ada enam orang siswa atau $24 \%$ yang memperoleh nilai cukup atau mendapat nilai sesuai dengan KKM (kriteria ketuntasan minimal), sedangkan Sembilan belas orang siswa atau $76 \%$ siswa memperoleh nilai kurang atau di bawah standar ketuntasan minimum yang sudah ditetapkan oleh sekolah. sesuai dengan histogram di bawah ini.

\section{Gambar 2 Hasil Kemampuan penguasaan verba bentuk-te}

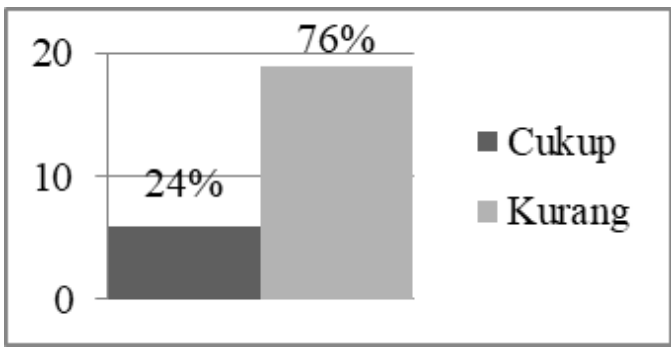

KULTURISTIK: Jurnal Bahasa dan Budaya E-ISSN: 2580-4456 P-ISSN: 2580-9334 Copyright $(\mathbf{C} 2018$ 
Vol. 2, No. 2, Juli 2018, 123

Available Online at https://ejournal.warmadewa.ac.id/index.php/kulturistik DOI: dx.doi.org/10.22225/kulturistik.2.2.718

Untuk mengetahui kemampuan siswa dalam penguasaan verba bentuk-te bahasa Jepang, siswa diberikan tes untuk memperoleh data penguasaan verba bentuk-te. Tes kemampuan penguasaan verba bentuk-te bahasa Jepang yang dikerjakan oleh siswa dinilai sesuai dengan kriteria penilaian yang telah ditetapkan oleh guru dan sekolah.

Dari segi kualitas, kemampuan siswa untuk penguasaan verba bentu-te dalam test yang sudah dilakukan, masih termasuk dalam kategori kurang memenuhi standar kriteria ketuntasan minimum (KKM). Peneliti memberikan sepuluh soal berupa kalimat rumpang tetang verba yang sesuai dalam kalimat tersebut dan termasuk verba bentuk-te.

Berdasarkan sebaran tes yang dikerjakan oleh siswa, dapat dijabarkan lebih lanjut yang berisi masing-masing item soal dan jawaban dari siswa yang dikelompokkan berdasarkan golongan kata kerja 1, 2, dan 3 terkait dengan verba bentukte.

Golongan kata kerja 1 (godan doushi)

Watashi wa mai asa 6 ji ni gakkou he...., gakkou de benkyoushimasu

Saya- Top setiap pagi 6 jam-Dat sekolah-Lok...., sekolah-Lok belajar-KKin

'saya setiap pagi pada jam 6.... ke sekolah, belajar di sekolah'

Soal di atas terdapat pada nomor 2 yang berbentuk kalimat majemuk yang menyatakan aktivitas yang berurutan. Untuk menjawab soal nomor dua diperlukan verba yang menyatakan pergerakan menuju ke suatu tempat. Verba yang paling tepat untuk mengisi titik rupang tersebut adalah verba iki-masu yang dalam bentuk kamus atau bentuk dasarnya adalah $i k-u$.Verba $i k-u$ termasuk dalam golongan kata keja pertama (godandoushi) menurut Koizumi dalam situmorang (2007: 9) verba golongan pertama merupakan verba konsonan (Koizumi dalam Situmorang, 2007: 9). Maksudnya bahwa kata dasar verba golongan pertama selalu di akhiri oleh bunyi konsonan. Jadi, yang mengalami perubahan atau konjugasi menurut koizumi adalah 'gobi' atau akhiran yang mengikuti kata dasar tersebut saja. Verba $i k-u$ memiliki morfem dasar / $i k /$, sedangkan morfem fungsinya adalah bunyi $/-u /$, jika dipadankan dengan bentuk te- maka akan mengalami konjugasi bunyi atau perubahan bunyi yaitu menjadi /tte/.

Secara keseluruhan verba $i k-u$ diubah ke dalam bentuk-te menjadi /itte/. Sedangkan jika melihat jawaban beberapa siswa yang menjawab shi-masu pada soal nomor dua akan menjadi Watashi wa mai asa 6 ji ni gakkou he shi-masu, gakkou de benkyoushimasu. Secara gramatikal hal itu tidak berterima dalam bahasa Jepang karena verba shi-masu memerlukan nomina sebagai objek yang dikenakan tindakan bukan nomina tempat. Tidak semua nomina bisa diikuti oleh verba shi-masu, melainkan terbatas pada nomina yang menyatakan arti perbuatan atau nomina verba saja.

Contoh nomina verba + shi-masu adalah benkyou + shi-masu yang memiiki arti belajar. Sehingga pada soal nomor dua siswa yang menjawab shi-masu sama sekali kurang tepat karena verba tersebut memerlukan nomina sebelum kata kerja shi-masu dan untuk menyambungkan klausa satu dengan yang lain diperlukan konjugasi verba bentuk-te. Sama halnya dengan soal nomor empat verba yang memerlukan verba dengan dimarkahi oleh pemarkah datif (partikel $\mathrm{ni}$ ) dengan kata kerja nonaksi yaitu $a-u$ atau a-imasu. Kata kerja yang tidak menggunakan patikel $n i$ adalah; membaca, berbicara, bekerja, makan,minum, mendengar, ber- 
Vol. 2, No. 2, Juli 2018, 124

Available Online at https://ejournal.warmadewa.ac.id/index.php/kulturistik DOI: dx.doi.org/10.22225/kulturistik.2.2.718

main, menyelidiki, dan kata kerja yang menggandung unsur pergerakan. Sedangkan kata kerja non aksi selalu dimarkai oleh partikel ni yang merupakan tujuan atau target dari suatu objek. Sehingga verba yang sesuai dengan titik rumpang pada nomor empat adalah $a-u$ atau $a$-imasu (Masuoka \& Dkk, 2000: 53).

Soal nomor enam memerlukan golongan kata keja pertama (godandoushi) yang dimarkahi oleh pemarkah datif ( $n i$ ) atau verba non aksi yang ditujukan kepada objek. Sehingga verba yang sesuai adalah atte. Pada soal nomor sembilan bisa dilengkapi dengan kata kerja yom- $u$ menjadi shinbun wo yom- $u$ yang berarti membaca koran, namun untuk menjadikan kata kerja kedalam bentuk progresif atau sedang berlangsung maka harus diubah ke dalam bentuk-te. Verba yom-u termasuk dalam golongan kata kerja pertama atau godandoushi. Jika dalam bentuk progresif atau bentuk-te menjadi yonde.

\section{Golongan kata kerja 2 (ichidan doushi)}

Watashi wa asa gohan wo....., sorekara syawaa wo abimasu saya- Top pagi nasi-AK...., setelah itu sower-Ak mandi-Kkin 'saya pagi.... nasi, setelah itu mandi dengan sower'

Soal di atas terdapat pada nomor 1 yang merupakan kalimat verba rumpang yang berbentuk kalimat majemuk. Soal pertama merupakan kalimat bentuk sambung dalam bahasa Jepang yang di konjungsikan dengan verba bentuk-te untuk menyambungkan klausa satu dan klausa lainnya yang menyatakan aktivitas yang berurutan. Untuk menjawab soal tersebut, siswa harus memahami terlebih dahulu arti dari objek klausa pertama (asa gohan) yang berarti sarapan sehingga verba yang sesuai dengan kalimat rumpang tersebut adalah verba tabe-ru. Namun untuk menjadikan bentuk sambung agar menjadi suatu kegiatan yang berurutan diperlukan pola konjugasi verba ke bentuk-te. Proses pembentukan verba bentuk-te dari verba dasar atau bentuk kamus tabe-ru terdiri dari gokan (morfem isi/morfem inti) dan gobi (morfem fungsi). Karena verba tabe-ru termasuk dalam golongan kata kerja ichidandoushi yang memiliki ciri verba kata dasarnya diakhiri oleh bunyi vokal yang berarti setelah kata dasar vokal (tabe) tersebut adalah morfem fungsinya atau gobi (ru) yang mengalami perubahan menjadi (te) sehingga konjugasi verba tabe-ru ke bentuk-te menjadi tabe-te. Sebagian besar siswa mejawab soal ini dengan benar, yaitu degan mejawab tabe-te. Verba bentuk-te merupakan bentuk sambung. Bentuk -te berfungsi sebagai bagian dari sebuah kalimat, jika bagian dari predikat dalam sebuah kalimat tersebut memiliki bentuk -te, yang memiliki arti bahwa kalimat tersebut belum berakhir dan ada predikat atau klausa yang mengikuti klausa sebelumnya (Makino, 1986: 466).

Pada soal nomor tujuh siswa harus memahami terlebih dahulu arti dari objek klausa pertama (eiga) yang berarti film, sehingga verba yang sesuai dengan kalimat rumpang tersebut adalah verba $m i$-ru, sehingga konjugasi verba mi-ru ke bentuk-te berubah menjadi mi-te. Pada soal nomor sepuluh siswa harus memahami terlebih dahulu arti dari objek klausa pertama terebi 'televisi', sehingga verba yang sesuai dengan kalimat rumpang tersebut adalah menonton atau melihat dalam bahasa Jepang selalu menggunakan verba $(m i-r u)$. Mi-ru termasuk dalam golongan kata kerja ichidandoushi yang memiliki ciri verba kata dasarnya diakhiri oleh bunyi vokal. Sehingga konjugasi verba mi-ru ke bentuk-te berubah menjadi mi-te. 
Vol. 2, No. 2, Juli 2018, 125

Available Online at https://ejournal.warmadewa.ac.id/index.php/kulturistik

DOI: dx.doi.org/10.22225/kulturistik.2.2.718

Golongan kata kerja 3 (henkaku doushi)

Watashi wa ima ichiba de kaimono wo...... imasu

Saya- Top sekarang pasar-Lok belanjaan-Ak.... -Morf(sedang)

'saya sekarang sedang.... belanjaan di pasar'

Soal di atas terdapat pada nomor 3 yang merupakan kalimat progresif yang sedang berlangsung sampai pada tuturan belum berakhir dengan kata lain aktivitas yang di ujarkan memiliki batas akhir. Sama halnya seperti penjelasan sebelumnya mengenai nomina verba + suru. Kata kaimono berarti belanjaan dalam hal ini dikenakan kasus sebagai akusatif yaitu kasus yang menandai nomina atau yang sejenisnya sebagai objek langsung yang dikenai tindakan. Untuk menjawab soal nomor tiga siswa harus mengetahi bahwa nomina verba 'kaimono' bisa dijadikan kata kerja dengan menambah su-ru menjadi kaimono wo su-ru yang berarti berbelanja, namun untuk menjadikan kata kerja ke dalam bentuk progresif atau sedang berlangsung maka harus diubah ke dalam bentuk-te. Verba su-ru termasuk dalam golongan kata kerja ketiga atau henkakudoushi sering disebut verba khusus karena perubahannya tidak beraturan, selain gobi yang mengalami perubahan go$k a n$ dalam verba ini juga ikut mengalami perubahan. Verba su-ru dengan gokan (su) + gobi (ru) ketika diubah dalam bentuk te-menjadi 'shi-te' dengan perubahan gokan dan gobi. Sehingga verba yang sesuai untuk mengisi titik rumpang pada soal nomor tiga adalah shi-te yang dibantu oleh verba bantu imasu yang berarti sedang.

Sebagian besar siswa menjawab benar, tetapi ada beberapa siswa yang memberikan jawaban dengan verba bentuk lampau yaitu shi-mashita. Mashita merupakan kala lampau yang sudah dilakukan pada saat tuturan sebelum diucapkan. Bila diletakkan pada titik rumpang tersebut maka akan menjadi 'Watashi wa ima ichiba de kaimono wo shi-mashita imasu' secara gramatikal tidak berterima karena adverbia ima menunjukkan keterangan sekarang yang memerlukan verba bukan lampau. Jika dibubuhi dengan verba bentuk lampau maka kalimat tersebut menjadi janggal sehingga untuk jawaban shi-mashita dinyatakan kurang tepat atau salah.

Pada soal nomor lima secara keseluruhan bermakna saya sedang... bahasa jepang di sekolah. Bila merujuk pada struktur bahasa indonesia maka akan berpola S-P-O-K yang dimana 'bahasa jepang' merupakan objek atau kasus akusatif yang kedudukannya sebagai objek langsung dari predikat. Sedangkan dalam bahasa Jepang struktur kalimat di atas berpola S-K-O-P. Hal inilah yang menyebabkan siswa bingung untuk menjawab soal kata kerja rumpang bahasa jepang. Jikalaupun struktur S-K-O-P di turunkan begitu saja dan diterjemahkan ke dalam bahasa indonesia kalimatnya akan menjadi ' saya sekolah bahasa jepang sedang belajar' yang secara semantik tidak berterima, namun siswa masih bisa menghubungkan objek yang sesuai dengan kata kerja 'bahasa jepang' dan melihat konteksnya dengan lokasi di sekolah.

Berarti memerlukan verba aksi atau aktivitas yang berkaitan dengan bahasa jepang yang dilakukan di sekolah. Verba yang sesuai adalah belajar atau benkyou -shi-masu( benkyou-su-ru). Setelah mengetahui verba yang sesuai dengan objek dari kalimat tersebut tugas siswa selanjutnya mengetahui perubahan bentuk-te dari verba benkyou-suru. Benkyou-su-ru (benkyou-shi-masu) merupakan kata kerja golongan ketiga atau henkakudoushi. Verba golongan ketiga ini sering disebut verba yang tidak beraturan selain gobi yang mengalami perubahan gokan da- 


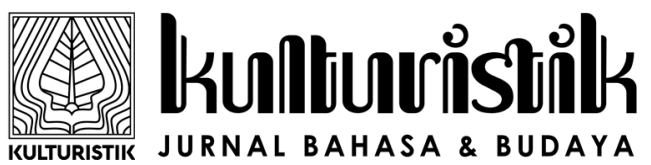

Vol. 2, No. 2, Juli 2018, 126

Available Online at https://ejournal.warmadewa.ac.id/index.php/kulturistik

DOI: dx.doi.org/10.22225/kulturistik.2.2.718

lam verba ini juga ikut mengalami perubahan. Seperti kasus benkyou-su-ru bila diubah ke dalam bentuk-te gokan (su) dan gobi (ru) akan berubah. Maka yang masih utuh adalah benkyou, sedangkan gokan (su) akan menjadi (shi) dan gobi (ru) menjadi (te) karena perubahan ke bentuk-te. Secara keseluruhan akan menjadi benkyou-shi-te.

Pada soal nomor delapan secara keseluruhan bermakna 'ibu saya sedang... masakan'. Bila merujuk pada struktur bahasa indonesia maka akan berpola S-P-O yang dimana dalam kasus ini objek atau kasus akusatif yang kedudukannya sebagai objek langsung adalah masak (ryouri), sedangkan dalam bahasa Jepang struktur kalimat di atas berpola S-O-P. Hal inilah yang menyebabkan siswa bingung untuk menjawab soal kata kerja rumpang bahasa jepang. Jikalaupun struktur S-O-P diturunkan begitu saja dan diterjemahkan ke dalam bahasa indonesia kalimatnya akan menjadi 'ibu saya masak sedang melakukan' yang secara gramatikal bahasa indonesia tidak berterima, namun siswa masih bisa menghubungkan objek yang sesuai dengan kata kerja masakan dalam bahasa Jepang dan melihat konteksnya dalam bentuk sedang karena menggunakan kata bantu verba imasu (iru). Verba bentuk te + iru ( te + imasu) digunakan untuk menyatakan perbuatan yang sedang berlangsung (Sutedi, 2003: 86). Imasu dalam kasus ini berdiri sebagai kata kerja yang menerangkan kata kerja di depannya atau dalam bahasa Indonesia disebut kata kerja penunjang (auxiliary verb), yaitu salah satu jenis kata kerja yang tidak mempunyai arti pokok, yang menunjukkan fungsi gramatikal (Sudjianto, 2004: 51-152).

Kata kerja yang sesuai dengan objek masakan adalah melakukan atau su-ru karena nomina verba 'ryouri' bisa dijadikan kata kerja dengan menambah su-ru menjadi ryouri wo su-ru yang berarti memasak, tetapi untuk menjadikan kata kerja dalam bentuk progresif atau sedang berlangsung maka harus diubah dalam bentuk-te+iru. Verba su-ru (shi-masu) merupakan kata kerja golongan ketiga atau henkakudoushi. Verba golongan ketiga ini sering disebut verba yang tidak beraturan selain gobi yang mengalami perubahan gokan dalam verba ini juga ikut mengalami perubahan. Seperti kasus ryouri wo su-ru bila diubah ke dalam bentuk -te gokan (su) dan gobi(ru) akan berubah. Perubahan gokan (su) akan menjadi (shi), sedangkan gobi (ru) menjadi (te) karena perubahan ke bentuk-te. Secara keseluruhan akan menjadi shi-te. Predikat dari kalimat di atas adalah shite imasu (shite iru) dan imasu berkedudukan sebagai kata kerja bantu (auxiliary verb).

Berdasarkan data test yang ditampilkan, baik secara kuantitatif maupun kualitatif, siswa masih belum memahami bagaimana perubahan verba ke bentukte, terutama karakteristik atau golongan verba yang memiliki perubahan stem berdasarkan golongan kata kerjanya. Diketahui berdasarkan analisis yang dilakukan terhadap hasil test, siswa masih mengalami kesulitan dalam memahami kosakata benda maupun kosakata kata kerja bahasa Jepang dengan benar karena kurangnya pembedaharaan kosakata dan kemampuan untuk mengubah verba ke konjugasi verba yang sesuai dengan aturan dalam bahasa Jepang.

Berdasarkan hasil test yang telah diuraikan diketahui bahwa kemampuan penguasaan verba bentuk-te dalam pembelajaran bahasa Jepang di kelas XI IPA SMA PGRI 6 Denpasar, 6 orang peserta didik atau (24\%) termasuk dalam kategori cukup atau sesuai dengan KKM dan 19 orang peserta didik atau (76\%) termasuk dalam kategori kurang atau di bawah KKM. Hal ini menandakan kemampuan peserta didik dalam penguasaan verba bentuk-te masih jauh dari kriteria yang diharapkan untuk mencapai kategori ketuntasan minimal. Pada hasil analisis 
Vol. 2, No. 2, Juli 2018, 127

Available Online at https://ejournal.warmadewa.ac.id/index.php/kulturistik DOI: dx.doi.org/10.22225/kulturistik.2.2.718

kualitatif ditemukan kesulitan yang dialami peserta didik terdapat pada golongan kata kerja godandoushi dan ichidandoushi terutama verba yang seharusnya memiliki perubahan konsonan yang rangkap $/ t /$ dan $/ t /$ yang tidak rangkap.

Berdasarkan hasil penelitian yang telah diuraikan di atas, terdapat temuantemuan bermakna, antara lain sebagai berikut. Pertama, kemampuan penguasaan verba bentuk-te pada peserta didik kelas XI IPA SMA PGRI 6 Denpasar tidak mencapai hasil yang diharapkan yaitu termasuk dalam kategori kurang, dengan nilai rata-rata yang diperoleh yaitu 50 . Terdapat enam orang siswa atau $24 \%$ yang memperoleh nilai cukup dan sembilan belas orang siswa atau $76 \%$ siswa yang memperoleh nilai kurang atau di bawah standar ketuntasan mínimum. Kedua, kesulitan dalam tes terdapat pada verba mi-ru dengan jawaban mi-tte, padahal verba mi-ru merupakan verba golongan kedua (ichidandoushi) dan konstruksi verba-te tinggal mengganti stem akhir (ru) dengan (te) sehingga menjadi mi-te.

Penguasaan verba bentuk-te pada peserta didik kelas XI IPA SMA PGRI 6 Denpasar ternyata masih perlu ditingkatkan terutama verba yang memiliki konjugasi bentu-te yang menandakan sedang berlangsung dan kegiatan berurutan. Artinya, perlu pengayaan lebih lanjut dalam rangka meningkatkan kemampuan penguasaan verba bentuk-te peserta didik kelas XI IPA SMA PGRI 6 Denpasar.

\section{SIMPULAN}

Dalam penelitian ini dapat ditarik simpulan sebagai berikut. Pertama, kemampuan penguasaan verba bentuk-te pada peserta didik kelas XI IPA SMA PGRI 6 Denpasar tidak mencapai hasil yang diharapkan yaitu termasuk dalam kategori kurang, dengan nilai rata-rata yang diperoleh yaitu 50. Terdapat enam orang siswa atau $24 \%$ yang memperoleh nilai cukup dan sembilan belas orang siswa atau $76 \%$ siswa yang memperoleh nilai kurang atau di bawah standar ketuntasan mínimum.

Kedua, kesulitan dalam tes terdapat pada verba mi-ru dengan jawaban $m i$ tte, padahal verba mi-ru merupakan verba golongan kedua (ichidandoushi) dan konstruksi verba-te tinggal mengganti stem akhir (ru) dengan (te) sehingga menjadi mi-te. Apabila dilihat dari kategori tingkat penguasaan siswa, nilai ratarata kemampuan penguasaan verba bentuk-te bahasa Jepang pada tes tergolong kategori kurang. Artinya, sebagian besar siswa belum menguasai verba bentuk-te.

\section{DAFTAR PUSTAKA}

Darlina, L., \& Al, E. (2018). Indonesian derivative verb affixes: a study of typological linguistics. E-Journal of Linguistics DOAJ Indexed, Vol. 12. N. Retrieved from https://ojs.unud.ac.id/index.php/eol/article/view/40702\%0A\% $0 \mathrm{~A}$

Depdiknas. (2008). Kamus besar bahasa Indonesia pusat bahasa. Jakarta: PT Gramedia Pustaka Utama.

Kartika, D. (2006). Analisis kontrastif bahasa Jepang dan bahasa Indonesia. LINGUA, Volume 5,

Makino, T. (1986). A dictionary of Japanese grammar. Japan: Minato.

Masuoka, T., \& Dkk. (2000). Nihongo bunpo serufu masutaa shirizu 3 kakujoshi. Tokyo: Kuroshio Shuppan.

Nugraha, M. W. (2011). Penguasaan aspek verba Te-imasu yang menyatakan kegiatan sedang berlangsung, kondisi, dan keadaan pada mahasiswa semester II jurusan pendidikan bahasa Jepang D3 Undiksha Singaraja. Universitas 


\section{Lisulturisistinlk \\ KUITURISTIK JURNAL BAHASA \& BUDAYA}

Vol. 2, No. 2, Juli 2018, 128

Available Online at https://ejournal.warmadewa.ac.id/index.php/kulturistik

DOI: dx.doi.org/10.22225/kulturistik.2.2.718

Pendidikan Ganesha.

Sarwono, J. (2006). Metode penelitian kuantitatif dan kualitatif. Yogyakarta: Graha Ilmu.

Simpen, I. W. (2008). Afiksasi bahasa Bali: sebuah kajian morfologi generatif. Jurnal Linguistika, 15.

Situmorang, H. (2007). Pengantar linguistik bahasa Jepang. Medan: USU press.

Sudjianto, D. A. (2004). Pengantar linguistik bahasa Jepang. Jakarta: Kesaint Blanc.

Sutedi, D. (2003). Dasar-dasar linguistik Bahasa Jepang. Bandung: Humaniora. 